\title{
PERAN AGAMA DALAM SISTEM PENGAWASAN
}

\author{
Oleh: \\ Cokorda Istri Kumara Dewi \\ Pasca Sarjana Ilmu Agama dan Kebudayaan \\ Universitas Hindu Indonesia, Denpasar \\ cok.inspektorat@mail.com
}

\begin{abstract}
The current government has funded the village for the sake of development in the hope that the community can play an active role in the development of the region. It is felt that the importance of supervision in the management of the development fund. The religion should be able to play a role in carrying out such supervision through the concept of karmaphala, hard work, honesty. This paper is the result of literature study which is analyzed by descriptive interpretative method.
\end{abstract}

Keywords: Role, Religion, Supervision, Village Development

\begin{abstract}
Abstrak
Pemerintah saat ini telah menggelontorkan dana pembangunan desa dengan harapan agar masyarakat dapat berperan aktif dalam pembangunan di wilayahnya. Sangat dirasakan pentingnya pengawasan dalam pengelolaan dana pembangunan dimaksud. Agama mestinya dapat berperan dalam menjalankan pengawasan dimaksud melalui konsep karmaphala, kerja keras, kejujuran. Tulisan ini adalah hasil studi kepustakaan yang dianalisis secara deskriptif interpretatif.
\end{abstract}

Kata kunci: Peran, Agama, Pengawasan, Pembangunan Desa

\section{PENDAHULUAN}

Kebijakan pemerintah membangun bangsa ini dari pinggiran (baca desa) merupakan angin segar dalam upaya pemerataan pembangunan. Salah satu jalan yang ditempuh adalah pemberian bantuan dana desa dalam jumlah yang cukup signifikan. Desa kini bisa merencananakan dan mengelola dana bantuan dimaksud sesuai dengan kepentingannya. Pendampingan dan pengawasan tentu saja sudah dilakukan. Namun demikian berdasarkan berita di media (kasus di Madura) masih juga elite-elite daerah yang tertangkap tangan oleh aparat penegak hokum akibat salah dalam mengelola dana tersebut. Sistem pengelolaan, pengawasan sudah cukup jelas, namun penyelewangan dana pembangunan masih juga terjadi. Dimana letak kekeliruannya jika demikian?

Tulisan ini mencoba menelaah persoalan tersebut dari sudut pandang agama Hindu, dengan pertimbangan bahwa kejadian penyelewengan dana bantuan dimaksud disebabkan oleh faktor mental para pengelola dana pembangunan dimaksud. Mental yang lemah dalam kaitan dengan pengelolaan keuangan pada umumnya disebabkan oleh nilai-nilai instrumental yang dipegang sehingga cenderung mengambil jalan pintas. Pada tulisan ini dicoba untuk menggali dan mengembangkan nilai-nilai intrinsic dalam membangun moral bangsa ini sehingga lebih kuat dalam menghadapi godaan-godaan material dengan jalan yang tidak dibenarkan.

Dengan kata lain bila nilai-nilai agama telah tertanam dalam hati sanubari setiap pengambil keputusan atau kuasa pengelola anggaran, di- 
harapkan penyelewengan tidak akan terjadi. Dengan asumsi bahwa setiap perbuatan jahat atau merugikan orang banyak atau Negara pasti akan mendapatkan hukuman, bisa terjadi di dunia nyata atau kelak nanti di alam baka sebagaimana diajarkan oleh agama.

\section{PEMBAHASAN}

\subsection{Peran Agama dalam MembangunNi- lai-NilaiIstrinsik}

Menurut Robertson (1986), harus diakui bahwa tidak setiap kebenaran secara normatif selalu sama dengan kebenaran agama secara praksis dalam kehidupan sosial karena pada kenyataannya tidak ada ide yang eksis dalam realitas empiris. Akan tetapi setidak-tidaknya agama memiliki dua dimensi penting bagi manusia, yakni menata pemikiran dan sikap manusia dan juga menata tindakannya dalam berbagai aspeknya. Secara tekstual agama menata pemikiran manusia sehingga secara kontekstual ia tidak tersesat dalam dunia pengalaman yang sarat dengan kontradiksi nilai dan norma. Perpaduan antara agama sebagai kebenaran tekstual dan kontekstual merupakan ideologi tertinggi dari sebuah cita-cita keberagamaan dalam setiap masyarakat manusia.

Walaupun demikian, dalam dunia yang semakin sempit oleh karena pesatnya perkembangan informasi dan teknologi, baik agama maupun masyarakat telah mengalami perubahan. Fungsi agama dalam masyarakat juga mengalami pergeseran-pergeseran yang semakin meyakinkan semakin jauh dari fungsinya semula karena kehadirannya tidak lagi dimonopoli oleh identitas yang bersifat kewilayahan. Identitas tidak lagi dapat ditemukan dalam batas-batas budaya masyarakat setempat karena arus barang dan orang semakin dinamis.

Dalam konteks pergeseran semacam ini simbol kebudayaan akhirnya, bukan lagi sebagai pengarah yang menentukan dalam suatu masyarakat yang dipatuhi dan memiliki daya paksa, tetapi menjadi alat politik bagi perjuangan kepentingan para pihak, baik individual, kelompok maupun institusi. Simbol-simbol agama misalnya, tidak hanya menjadi penunjuk arah dari suatu praktik yang berhubungan dengan religiusitas, tetapi juga bagi sebagian orang, kelompok atau institusi menjadi alat bagi legitimasi atas keberadaan dan kepentingan.
Agama berfungsi mengesahkan keberadaan dan tindakan-tindakan yang bisa terjadi menyimpang dari substansi ajaran karena citra telah mewakili suatu realitas keagamaan itu sendiri. Agama dipraktikkan sebagai bagian dari pengendalian sosial dan identifikasi diri untuk pemosisian individu, kelompok, dan institusi dalam serangkaian transaksi sosial yang dinamis dan kontekstual. Simbol-simbol budaya telah menjadi alat bagi penegasan autentisitas kelompok yang keberadaannya menjadi bagian dari sistem sosial global dengan pertentangan nilai yang semakin tajam (Abdullah, 2006).

Menurut Kahmad (2000) yang mengutip pandangan Glock dan Stark menyebutkan ada lima dimensi agama. Pertama, dimensi keyakinan. Dimensi ini berisikan pengharapan sambil berpegang teguh pada teologis tertentu. Kedua, dimensi praktik agama yang meliputi perilaku simbolik dari makna-makna keagamaan yang terkandung didalamnya. Ketiga, dimensi pengalaman keagamaan yang merujuk pada seluruh keterlibatan subjektif dan individual dengan hal-hal yang suci dari suatu agama. Keempat, dimensi pengetahuan agama, artinya orang beragama memiliki pengetahuan tentang keyakinan, ritus, kitab suci, dan tradisi. Kelima, dimensi konsekuensi yang mengacu pada identifikasi akibat-akibat keyakinan, praktik, pengalaman, dan pengetahuan seseorang dari hari ke hari.

Dari uraian di atas jelas bahwa agama semestinya dijadikan rujukan dalam bertingkah laku baik secara personal maupun dalam kaitan dengan dunia sosialnya. Agama juga memberi keyakinan akan konsekuensi dari system keyakinan dimaksud. Dalam ajaran Hindu dikenal dengan istilah hukum Karmaphala. Suatu tindakan akan menimbulkan akibat.

Menurut Talcot Parson sebagaimana dikutip Grondona (2006), nilai mungkin dianggap ebuah elemen di dalam sistem simbol konvensional yang berfungsisebagai kriteria untuk menyeleksi alternatif-alternatif yang tersedia dalam sembarang situasi. Hanya negara-negara dengan system nilai yang condong kepada keputusan yang tahan godaan akan mampu memiliki pembangunan yang cepat dan berkelanjutan. Godaan adalah pembawa harapan jangka pendek, sementara pembangunan ekonomi adalah sebuah proses jangka panjang.

Ada dua kategori nilai: intrinsik dan instrumental. Nilai-nilai intrinsik adalah nilai-nilai 
yang dijunjung tanpa hirau manfaat atau biayanya. Patriotisme sebagai sebuah nilai, menuntut pengorbanan dan kadang-kadang "tidak menguntungkan" bagi kehidupan seseorang. Walaupun demikian ratusan orang bersedia mati demi nilai dan demi mempertahankan negaranya. Sementara itu sebuah nilai menjadi instrumental ketika masyarakat mendukungnya hanya karena nilai itu secara langsung bermanfaat baginya. Jika keputusan pembangunan hanya menjawab nilai instrumental dari sifat dasar ekonomi, seperti meningkatkan kekayaan, usaha-usaha Negara akan turun setelah tingkat kekayaan tertentu tercapai.

Dalam pandangan Cabin (2006: 87-95) terdapat beberapa factor penting dalam menanamkan nilai instrinsik tersebut antara lain: Perta$m a$, Agama, Agama sepertinya memiliki wajah ganda dalam hubungannya dengan masalah pembangunan, di satu sisi agama bisa menjadi faktor pendorong tetapi sekaligus pula dapat menjadi penghambat. Menurut Cabin, agama yang terlalu memihak kepada kelompok miskin dalam arti memberikan pembenaran kepada kemiskinan sebagai sesuatu yang memang datang dari langit atau sebagai takdir, kurang memberi kontribusi positif terhadap budaya pembangunan. Kedua, Kepercayaan dalam Individu. Mesin utama pembangunan adalah kerja dan kreativitas individu-individu. Apa yang menyebabkan mereka bekerja keras dan menghasilkan penemuan adalah sebuah iklim kebebasan yang membuat mereka memegang kendali nasib mereka sendiri. Memercayai individu, meyakini individu, merupakan salah satu elemen system nilai yang memihak pembangunan.

Sebaliknya, ketidakpercayaan terhadap individu, yang tercermin dalam pengawasan dan kendali, merupakan tipikal masyarakat yang menolak pembangunan. Ketiga, Tatanan Moral. Ada tiga tingkat dasar moralitas. Yang paling tinggi adalah mengutamakan kepentingan orang lain dan meniadakan diri sendiri - moralitas orang suci dan martir. Yang terendah adalah moralitas penjahat - tidak menghormati hak-hak orang lain dan hukum. Moralitas tingkat tengah adalah apa yang disebut Raymond Aron "egoisme yang masuk akal" - individu tidak bersikap seperti orang suci atau penjahat, namun secara masuk akal mencari kesejahteraannya sendiri dalam batasan-batasan tanggung jawab sosial dan hukum.
Keempat, Dua Konsep Kekayaan. Dalam masyarakat yang menolak pembangunan, kekayaan tak lain terdiri atas apa yang ada; di masyarakat yang memihakpembangunankekayaantak lain terdiriatasapa yang belumada.Keli$m a$, NilaiKerja.Kerjatakterlaludihargaidalammasyarakat yang menolakpembangunan; kondisisebaliknyatampakpadanegara-negara yang telahmencapai kemakmuran seperti Eropa Barat, Amerika Utara dan Asia Timur. Secara ringkas dapat dikatakan bahwanilai-nilaiinstrinsik yang perlu ditanamkan untuk mencapai kemajuan dalam pembangunan bangsa adalah budaya hidup hemat, investasi, kerja keras, pendidikan, organisasi, dan disiplin (Fukuyama, 2002).

Dalam pandangan agama Hindu terdapat beberapa konsep yang dapat ditawarkan dalam membangun nilai-nilai intrinsik sebagai berikut.

\section{Hendaklah orang yang berkuasaitu- makanmakanan yang suci yang berisi keenam rasa; hendaklah ia mengecap ke- nikmatan pergaulan dan selalu dilayani istri yang patut baginya serta indah rupa- nya. Karena kekayaannya menjadilah ia berkuasa, maka hendaklah selalu member sedekah dan berbuat kebajikan. Itu semua, menurut ajaran karma, adalah buah dari padalaku yang teguh jujur (dalam kehidu- pan yang sudah-sudah (Niti Sastra, Sar- gah XIII.11)}

Sloka dalam Niti Sastra tersebut jelas menekankan pada ajaran Karma phala, bahwa apa yang diperoleh saat ini adalah buah karma dari perbuatan di masa lalu. Dengan kata lain cepat atau lambat segala karma yang dilakukan pasti akan mengahasilkan pahala. Persoalannya cepat atau lambat maka segala perbuatan akan mendatangkan hasil. Oleh karena itu hal terbaik yang dapat dilakukan adalah melakukan tindakan yang tidak melanggar hukum agar terhindar dari jeratan hukum.

Konsep lainnya terkait dengan penanaman nilai-nilai intrinsik dapat ditawarkan tentang cara memperoleh kekayaan dengan kerja keras sebagai berikut. 
Kekayaan terbaik adalah uang yang didapat sendiri dari kerja keras (Niti Sastra, Sargah II.2).

Jika nilai-nilai ini telah tertanam dengan baik maka selemah apapun pengawasan maka sebesar apapun dana yang dipercayakan kepada seseorang untuk dikelola, serta sesederhana apapun pengawasan yang dilakukan maka dana dimaksud akan digunakan sebagaimana mestinya. Para pengelola dana negara tidak akan tergoda untuk melakukan korupsi, sebab mereka tahu bahwa itu bukan haknya. Seorang pekerja keras tahu bahwa dia akan mengambil haknya saja karena memang itulah yang boleh ia terima sesuai dengan petunjuk pelaksanaan dana yang dikelolanya.

Dana yang diperoleh karena usaha hendaklah dibagi tiga yaitu untuk biaya mencapai dharma, bagian yang kedua untuk memenuhi kama, bagian ketiga untuk kegiatan usaha di bidang ekonomi agar berkembang kembali (Sarasamuccaya 262)

Harus diingat pula bahwa sekecil apapun rejeki yang diterima, di situ ada jasa atau jerih payah orang lain yang melekat. Oleh karena itu wajib bagi umat Hindu untuk menyisihkan penghasilannya untuk menolong mereka yang benar-benar membutuhkan. Bantuan dimaksud bisa berupa dana, jasa, ataupun berbagi pengetahuan yang dapat membantu orang lain untuk terbebas dari beban ekonomi maupun beban lainnya. Artinya bantuan yang diberikan sama sekali tidak dimaksud membuat orang menjadi malas, namun bagaimana mereka yang belum beruntung bisa bangkit dari keterpurukan sehingga bangkit untuk berusaha dalam mewu- judkan eksistensinya sebagai umat Tuhan yang selalu siap bekerja keras.

Pangkal kesulitan yang terbesar bagi manusia tersembunyi dalam dirinya sendiri. Nafsu loba menyebabkan orang tak dapat mencapai kebaikan yang dicita-citakannya. Itu pula yang menyebabkan semua pengetahuan yang dikumpulkan sejak lama jadi hilang dan akhirnya habis sama sekali.

Karena tidak bisa mencapai cita-citata di, budi yang baik pun berbalik menjadi keburukan (Niti Sastra, Sargah XIII)

Di sinilah pangkal persoalannya, sebaik apapun program yang direncanakan, seketat apapun pengawasan yang dilakukan, jika para pengguna anggaran tidak mampu mengendalikan diri, maka akan selalu muncul upaya untuk memperkaya diri sendiri dengan cara-cara yang tidak dibenarkan baik oleh agama maupum hukum yang berlaku.

\section{PENUTUP}

Dari paparan ringkas di atas dapat ditarik simpulan sebagai berikut. Pertama, penanaman nilai-nilai intrinsik menjadi sangat penting dalam pembangunan bangsa secara keseluruhan. Bangsa yang hanya tertarik pada nilai-nilai instrumental akan sulit membangun karakter bangsa karena cenderung bersifat sementara dan lemah terhadap godaan-godaan duniawi sesaat. Kedua, bahwa konsep-konsep yang ditawarkan oleh agama dalam memberikan tuntunan agar masyarakat memiliki karakter yang kuat dalam memberikan pengawasan dalam pengelolaan aset yang dipercayakan kepadanya tersebar cukup banyak. 


\section{DAFTAR PUSTAKA}

Abdullah, Irwan. 2006. Konstruksi dan Reproduksi Kebudayaan.Yogyakarta :PustakaPelajar.

Cabin, Philippe. 2005. Di BalikPanggungDominasi, Sosiologiala Pierre Bourdieu dalam Giddens, Anthony, Daniel Bell, Michel Forse.etc. 2005. Sosiologi, Sejarahdan Berbagai Pemikirannya oleh Giddens, Anthony, Daniel Bell, Michel Forse.etc. Yogjakarta: KreasiWacana.

Fukuyama, Francis. 2002. The Great Disruption. Hakikat Manusia dan Rekonstitusi Tatanan Sosial. Yogyakarta: Qalam.

Grondona, Mariano. 2006. Tipologi Budaya Pembangunan Ekonomi dalam Kebangkitan Peran Budaya. Bagaimana Nilai-Nilai Membentuk Kemajuan Manusia. Jakarta: LP3ES

Huntington, Samuel P. 2006. Kebangkitan Peran Budaya. Bagaimana Nilai-Nilai Membentuk Kemajuan Manusia. Jakarta : LP3ES

Kahmad,Dadang. 2000. Sosilogi Agama. Bandung: PT Remaja Rosdakarya.

Koentjaraningrat. 1985. Kebudayaan Mentalitas dan Pembangunan. Jakarta: PT Gramedia.

PGAHN 6 TahunSingaraja. 1971. NitiSastraDalamBentukKakawin. Denpasar: Pemda Tingkat I Bali.

Robertson, Roland. 1986. Sosiologi Agama. Aksara Persada Offset.

Utama, I Wayan Budi. 2008. Modal Budaya dan Modal Sosial dalam Kepemimpinan: Telaah Isi Kakawin Niti Sastra dalam Dharma Smrti, Jurnal Ilmu Agama \& Kebudayaan. Denpasar : Program Magister Ilmu Agama \& Kebudayaan Universitas Hindu Indonesia. 